Florida International University FIU Digital Commons

$5-1982$

\title{
Comparative management performance of Chinese specialty restaurant and American specialty restaurant in Miami area
}

Shu-Nuan Tanya Chin

Florida International University

DOI: $10.25148 /$ etd.FI14060808

Follow this and additional works at: https://digitalcommons.fiu.edu/etd

Part of the Food and Beverage Management Commons

\section{Recommended Citation}

Chin, Shu-Nuan Tanya, "Comparative management performance of Chinese specialty restaurant and American specialty restaurant in Miami area" (1982). FIU Electronic Theses and Dissertations. 2333.

https://digitalcommons.fiu.edu/etd/2333 


\section{COMPARATIVE MANAGEMENT PERFORMANCE}

OF CHINESE SPECIALTY RESTAURANT

AND AMERICAN SPECIALTY RESTAURANT

IN MIAMI AREA

by

$$
\text { Shu-Nuan Tanya Chin }
$$

A thesis submitted in partial fulfillment of the requirements for the degree of

MASTER OF SCIENCE

in

School of Hospitality Management

at

Florida International University

May 1982 


\section{COMPARATIVE MANAGEMENT PERFORMANCE \\ OF CHINESE SPECIALTY RESTAURANT \\ AND AMERICAN SPECIALTY RESTAURANT \\ IN MIAMI AREA}

\section{by}

$$
\text { Shu-Nuan Tanya Chin }
$$

A thesis submitted in partial fulfillment of the requirements for the degree of

MASTER OF SCIENCE

in

School of Hospitality Management

at

Florida International University

Committee in charge:

Chairperson, Dr. Lendal Kotschevar Professor Peter Martini

May 1982 
To professors: Lendal Kotschevar

Peter Martini

This thesis, having been approved in respect to form and mechanical execution, is referred to you for judgment upon its substantial merit.

Dean Gerald W. Lattin

School of Hospitality

Management

This thesis of Shu-Nuan Tanya Chin is approved.

Professor

Professor

Major professor

Date of Examination: May, 1982 
Shu-Nuan Tanya Chin was born in Taiwan in 1954. She is a graduate of Soochow University (Taipei, Taiwan) where she received a Bachelor of Art degree with a major in Japanese Literature.

After finishing the university, she worked in a big hotel which is a growing industry in Taiwan.

This experience convinced her of the longterm advantages of attending a hotel school. So she decided to continue her advanced education in that field at Florida International University. She wrote this project as a partial fulfillment of the requirements of the Degree of Master of Science in Hotel Management. 
Special thanks are due Dr. Iendal Kotschevar, both for teaching me much of what I know about restaurant management and for furnishing me with a variety of helpful materials.

In addition, I appreciate the teaching and the help of professor Peter Martini.

Last, but certainly not least, I owe a special de t to all the faculty in the Department of Hospitality hanagement at Florida International University who have contributed directly or indirectly to the preparatior of this project. Thus, while individual names are not listed, their contrijutions are nonetheless recognized and appreciated. 
TABLE OF CONTENTS

\section{PRELIMINARIES}

Biographical Sketch / vi Acknowledgements / vii

Table of Contents / viii

The List of Tables / $\mathrm{x}$

The List of Figures / xi

I. THE PRO3LEM AND ITS SETTINA

The Statement of the Problem / 1

The Subproblems / 1

The first subproblem / 1

The second subproblem / 1

The Hypotheses / 2

The first hypothesis / 2

The second hypothesis / 2

The Delimitations / 2

The Definitions of Terms / 2

The Assumptions / 5

The first assumption / 5

The second assumption / 5

The Importance of the Study / 5

II.THE REVIEW OF THE RELATED LITERATURE

A Historical Overview / 10

A Framework for Comparative Management Study / 13

Management philosophy / 19

Management practice / 20

Management performance / 22

Summary / 25

III.DESI IN OF THE STUDY

Conceptual Framework of the Study / 28

The Research llethodology / 30

Sample Design / 30

Questionnaire Design / 31

IV.MANA XEMENT PRACTICE AND MANA IEMENT PERFORMANCE ANALYSIS

Response Data / 34

Management Practice Rating / 34 
Management Performance Rating / 44

Management Practice and Management Performance Correlation Test / 48

V. PROFITABILITY ANALYSIS

Profitability Comparison between Chinese and American Specialty Restaurant / 52

Affecting Factors Identification / 55

VI. CONCLUSIONS AND RECOMMENDATIONS

Conclusions / 64

Recommendations / 65

BIB LIOGRAPHY

APPENDIXES

69

A. Title of the Study / 69

B. Cover Letter / 70

C. Clarification of Terms / 71

D. Questionnaire / 72 
4- 1 Recovery Rate of The Questionnaires

4- 2 Management Practice - Customer Opinion Collection

4 - 3 Inanagement Practice - Decoration

4- 4 Management Practice - Special Promotion

4- 5 lianagement Practice - Employee Development Frogram

4- 6 Management Practice - Staffing

4- 7 lianagement Practice - Adverticing

4- 8 Management Practice - Department or People in Charge

4 - of Marketing

4- 9 lianagement Practice - Planning \& Control Techniques

4-10 Distribution of Tianagement Practice Rating

4-11 Distribution of Expected Frequencies of Management Practice

4-12 Computation of $x_{c}{ }^{2}$ of Management fractice

4-13 Distribution \& Average Fating of Sales Frowth Rate

4-14 Distribution \& Average Rating of Fatron Return Rate

4-15 Distribution \& Average Rating of Imployee Turnover Pate

4-16 Distrioution $\varepsilon$ Average Ratin of Productivity

$4-1$ ? Distribution of liana Eemert Performance latine

4-18 Somputation of ixpected Frequenciea - laracement Ferformance Rating

4-19 Distrivution of ranagement Ferformance Aainst Inanasement Fractice

4-20 expected Frequency of Tanament Ferformance Acainst Ilanagement Practice

5- 1 The occurrence of Profitability of Chinece and American Restaurant

5- 2 Computation of Expected Frequencies - Profitability of Chinese and American Restaurant

5- 3 Computation of $\mathrm{Y}_{\mathrm{c}}{ }^{2}$ - Profitaoility of chinese and American Restaurant

5- 4 Distribution of Frofitaility Against Restaurant Age

5- 5 Computation of Expected Frequencies - Profitability Against Restaurant Age

5- 6 Computation of $\mathrm{Kc}_{\mathrm{c}}{ }^{2}$ - Profitability Against Restaurant Age

5- $?$ Distribution of Profitability Against Bestaurant Size

5- 8 Distribution of Profitability Against Business Form

5- 9 Distribution of Frofitability Against Location 


\section{THE IIST OR FI IURES}

FIGURE

PA

3-1 Conceptual Framework of The Study 29

3-2 Correlation Factors of The Frofitability 29

5-1 Curve of Profitability Rating vs. No. of Seat 58

5-2 Curve of Profitability Rating vs. Form of Crganization 60 
CHAPTEP I 


\section{The Statement of the Problem}

This research proposes to identify and evaluate the existing management practices and management performance of two categories of restaurants by comparing the Chinses specialty restaurant to the American specialty restaurant in the Miami, Florida area.

The Subproblems

1. The first subproblem. The first subproblem is to identify and to evaluate the existing management practices used by the managers of these two categories of restaurants.

2. The second subproblem. The second subproblem is to identify and to evaluate the management performance in these two categories of restaurants. 
The Hypotheses

The first hypothesis is that the management practices employed by the Chinese managers are different from those employed by the American managers.

The second hypothesis is that different management practices can lead to different management performance.

The Delimitations

The field of study will be limited to selected restaurants in the Miami, Florida area.

This study will be limited to Chinese specialty restaurants and American specialty restaurants. The Definitions of Terms

Management. The act, art, or techniques of managing; or of controlling and exercising discretionary powers in the direction of an enterprise. The things that are done to plan, guide, direct, control and supervise the operation of a business. 1

\footnotetext{
${ }^{1}$ Donald T. Clark and Bert A. Gottfried, $\frac{\text { University Dictionary of Business and Finance }}{\text { (New York: Thomas Y. CroweTT Co., 1957), p. } 221 .}$
} 
Management performance. Skills of management measured in terms of dollars or in ratios that can be compared with other companies. Some of these ratios are profit ratios, growth ratios, labor cost percentages, food cost percentages, employee turnover rate, absenteeism rate, employee productivity, etc. ${ }^{2}$

Specialty restaurant. Foodservice establishments featuring dishes of a specific nation, ethnic origin, or type. ${ }^{3}$

Management by objective. A generic titie used to express both the methods and philosophy of management which embrace the continuous review of management objectives and achievement, management trajing, and the reinforcement of management motivation by systematic approaches to selection, salary and succession. 4

${ }^{2}$ Norman D. Moore, Dictionary of Business Finance and Investment (Dayton, Ohio: Investor's Systems, Inc., 1975), p. 259.

${ }^{3}$ C. Dewitt Coffman, Hospitality For Sale (East Lansing, Michigan: The Educational Institute of the American Hotel \& Motel Association, 1980), p. 5.

${ }^{4} A$. I. Marsh and E. 0. Evans, The Dictionary of Industrial Relations (London: Hutchinson Educational Ltd., 1973), p. 194. 
Management development. An organized program for management personnel, usually at the top or middle level for the purpose of developing and improving managerial functions, including planning, organizing, motivating, and controlling the activities of an organization. Management development programs concern themselves not only with specific knowledge and skills, but also with the basic attitudes which permit management to function effectively. 5

Employee turnover. Movement of individuals into, through, and out of an organization. Turnover can be statistically defined as the total number (or percentage) of separations that occurs over a given time period. The turnover rate is an important indicator of the morale and health of an organization. 6

5Harold S. Roberts, Roberts' Dictionary of Industrial Relations (Washington, D.C.: The Bureau of National Affairs, Inc., 1971), p. 4.

${ }^{6}$ Jay M. Shafritz, Dictionary of Personnel Management and Labor Relations (Oak Park, Illinois: Moore Pubtishing Company, Inc., 1980), p. 339. 
Absenteeism. The practice of a worker of fajling to report for work for a period of one or more days or shifts, when he has been assigned to or scheduled for work. 7

The As sumptions

The first assumption. The first assumption is that the Chinese restaurant will continue to play an important role in the American life.

The second assumption. The second assumption is that the research on the restaurants in the Miami area will be representative of the whole United States.

The Importance of the Study

China, with a total land area slightly larger than the United States, has one of the oldest continuous cultures in the world, dating from at least 1766 B.C. Because her arts, including the art of cooking, have developed independently of the West, they represent a unique genre.

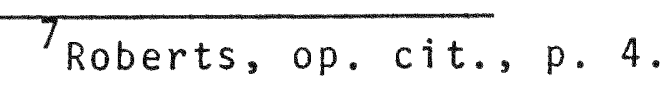


China's culinary art remained largely unknown to the Western world until the mid-1800s, when Chinese cooking was introduced to the United States by immigrants (mainly from the province of Kuangtung in Southeastern China) who came to the United States to work in the gold mines and in the building of the railroads. Before many decades had passed, acceptance of Chinese food had grown to such an extent that virtually every fair-sized community in the United States had at least one Chinese restaurant. The $1950 \mathrm{~s}$ and 1960 s saw a phenomenal interest in "eating chinese". 8 During the 1970 s along with people's enjoying Chinese dishes, Chinese restaurants are increasing at a rapid rate. There are 250 Chinese restaurants in the Miami area. How are they run? What performance have they made? Because of exposure to different management philosophies, will their management practices be different from those of American restaurant? Should there be any difference, will they influence the performance? Is there any lesson to be learned from manage-

\footnotetext{
${ }^{8}$ Nobuko Sakamoto, The People's Republic of China Cookbook (New York: Random House, Inc., 1977), p. 1 .
} 
ment practices found in chinese specialty restaurants?

Could Chinese specialty restaurants profit from management practices found in American specialty

restaurants? Is it possible in the American economy for a specialty restaurant built on a highly foreign food and service to compete successfully? 
CHAPTER II 


\section{THE REVIEW}

\section{OF THE RELATED LITERATURE}

Some years ago, a wag invented a new answer to the perennial question, "How's your wife?" He answered, "Compared to what?", thereby illustrating the necessity for comparison in human affairs. While this humorist cannot be credited with the development of the comparative method, this method has been explicitly incorporated into the publications, curricula, and research programs of such disciplines as economics, sociology, psychology, law, education, religion, and literature. In business administration, formal interest in comparisons is more recent, although books, articles, courses, and research projects have been multiplying since the early 1950's--especially in marketing and management. ${ }^{1}$ In restaurant management, however, the comparative study is little known. Therefore, applicable information is little or nothing. Let's take a look at the development of comparative approach.

1J. Boddewyn, "The Comparative Approach to the Study of Business Administration," Academy of Management Journal, vol. 8, No. 4 (Dec. 1965 ), p. 261. 
A Historical Overview

The controversy over comparative versus case analysis is actually of only recent vintage. Just as in everyday speech the individual discovers that to communicate with others he must be willing to stereotype reality--if only for the sake of brevity--the Greek approach to knowledge (herein defined as the set of tested propositions) was based on the premise that there are certain recurrent patterns in nature. In medicine this meant that diseases could be classified and treated as a group. To Plato there are "ideal types," or forms, which only the very gifted can intuit. To Aristotle, who demanded more rigorous standards of proof, there are comparabilities, or regularities, in phenomena which those who are talented and "immersed" in the data can abstract.

By the seventeenth century, when the canons of modern scientific inquiry were being developed, the Judaeo-Christian influence had discarded the Greek cyclical view of history, replacing it with a stress on development and evolution. The notion of prere- 
quisite, universal stages of historical development of Turgot was carried on by the "state of nature" political theorists, while the Cartesian search for "laws of nature" also relied heavily on comparison in its use of the analogy. In social thought, Leibniz and others began to use analogies from physiology to society, the genesis of modern "functionalism."

In the mid-nineteenth century, however, it appeared that by emphasizing the universal and the regular, science was actually conservative and tended only to support the existing state of affairs. The publication of the Malthusian hypothesis indeed made economics seem a dismal science. Romanticists and humanitarians joined forces, and the prevailing form of social inquiry of such men as Mill and Ranke focused on the particular; the argument advanced was that a11 social phenomena are unique and cannot be compared because there are "too many" factors involved. Because the main reason for university course offerings in 
history, political science, and anthropology was often merely to produce competent monographwriters, bureaucrats, and colonial ethnographers, the bias against search for regularity in the socalled "soft" social sciences became nearly selfsustaining.

At the end of the nineteenth century, spectacular advances in geology and biology, due in part to massive amounts of collected data, made their impact on the social sciences. The result was the early attempt to derive propositions about man and social phenomena in general by such men as Dilthey, Weber, Bagehot, and Bryce in history and political science; by Tylor, Morgan, and Frazer in anthropology. Dissatisfied with the fact that theories of such scholars had little accumulated information to back them up, the next generation of researchers began to amass as much data as it could with an appalling lack of uniformity among investigators as to the meaning--immediate or ultimate--of the "data" being collected. This antitheoretical bias was particularly dominant in the $1920^{\prime} \mathrm{s}$. 
As advances in theory and methodology, in sociology and psychology, made their way into the rest of the social sciences, partly through the influence of Linton in anthropology and Merriam in political science, a renewed interest in comparative analysis blossomed. 2 During the past two decades international business operations have become massive in scale and are continuing their rapid expansion. Corrolary to this development is the ever increasing flow of publications that deal with a wide range of issues concerning international business and comparative management. ${ }^{3}$

A Framework for Comparative Management Study

A perennial argument between those who believe that management is a science governed by universal principles and those who say that these principles are culture-bound will probably be intensified as a result of current cross-cultural research in management science.

${ }^{2}$ Michael Haas, "Comparative Analysis," Western Political Quarterly, XV, No. 2 (June 1962), $\overline{p p .294-}$ 303 .

${ }^{3}$ Hans Schollhammer, "Strategies and Methodologies in International Business and Comparative Management Research," Management International Review, Vol. 13, No. $6(1973)$, p. 17. 
Particularly, the needs of developing countries for advanced technical and managerial know-how in their economic development efforts will compel us to ascertain which elements of American management know-how are transferable and which are not. It is indeed true that to date many management "process school" theorists believe that "management is management wherever practiced, a universal profession whose principles can be applied in every organized form of human activity. " 4 A mere glance at the existing textbooks on principles of management will validate this point. Harbison and Myers, after studying management practices in 23 countries, came to the conclusion that "Organization building has its logic... which rests upon the development of management... and...there is a general logic of management development which has applicability both to advanced and industrializing countries in the modern world." 5

${ }^{4}$ Harwood E. Merri11, "Listening Post," Management News, Vo1. 36 (Jan. 1963), No. 1, p. 451. ${ }^{5}$ Frederick Harbison and Charles Myers, Management in the Industrial World (New York: McGrawHiT1 Book Company, 1959), p. 117. 
However, many cross-cultural studies of management practices have challenged this contention of the so-called universalists. Gonzalez and McMillan, in their study of the applicability of the American management philosophy in Brazil, found that the management philosophy is culturebound, that "American philosophy of management is not universally applicable." 6

Winston 0berg, in his study of "Cross-Cultural Perspectives on Management Principles," argues that if the ground rules under which the manager operates are different in different dultures and/or countries, then it would be quite fruitless to search for a common set of strategies of management. From his overseas experience and empirical research in Brazil and the United States he concluded that "Cultural differences from one country ot another are more significant than many writers (on management theory) now appear to recognize.... If management principles

${ }^{6}$ Richard F. Gonzalez and Claude McMillan, Jr., "The University of American Management Philosophy," Journal of the Academy of Management, Vol. 4, No. 1 (ApriT 1961), p. 39. 
are to be truly universal... they must face up to the challenge of other cultures and other business climates... A (Universalist claim) is hardly warranted by either evidence or intuition at this stage in the development of management theory. "7

Farmer and Richman, in their article, "A model for Research in Comparative Management, "have also stressed the importance of external environmental factors on the efficiency of the manager. They argued that:

Most studies of management have taken place within a 'black box' labeled management, without much concern for the external environment in which the firm may operate. As long as this external environment is about the same for all firms, the approach is valid; however, in cases where the environment differs significantly,... as is the case between nations, present theory (of management) is inadequate to explain comparative differentials in efficiency.

\footnotetext{
Tinston Oberg, "Cross-Cultural Perspectives on Management Principles," Journal of the Academy of Management, Vo1. 6, No. 2 (June 1963), pp. 141142 .

${ }^{8}$ Richard Farmer and Barry Richman, "A Model for Research in Comparative Management," California Management Review, (Winter 1964), pp. 141-142.
} 
Based on these premises, they have offered a model to ascertain the influences of what they call external constraints on managerial efficiency. The general classes of external constraints considered by them are:

1. Educational Characteristics

2. Sociological Characteristics

3. Political and Legal Characteristics

4. Economic Characteristics

To evaluate the management performance in any country, they argue, one should take into consideration all the above factors. For judging relative performance of managers in different countries they also have proposed a tentative ranking for the individual factors discussed above.

It is indeed true that external environmental factors do affect management performance. To this extent, Farmer and Richman's insightful analysis of external constraints may provide a sound basis for further theoretical developments in management. 
However, there is evidence that certain elements of American management know-how ${ }^{9}$ are successfully applied in altogether different cultures and environments. Gonzalez and McMillan, who have argued that management philosophies are culturebound, admit that "American management is most highly respected abroad... and American management know-how...has yielded great dividends for the host country." 10

Management performance in a given industry with a given technical know-how is dependent upon the way in which the manager carries out the practice of planning, organizing, staffing, directing, and controlling. However, the management practices is dependent on both the external environmental factors and the management philosophy. Thus, there are three key variables in the study: Management philosophy, Management practice, and Management performance.

\footnotetext{
${ }^{9}$ By American management know-how, it means various techniques used by the manager, in a largescale firm in the United States, to carry out his basic functions of planning, organizing, staffing, directing, and controlling.

10 Gonzalez and McMillan, op. cit., p. 39.
} 


\section{Management Philosophy}

The concept of management philosophy is understood as the expressed and implied attitude or relationships of a firm with some of its external and internal agents such as:

(a) Consumer

(i.e., the company's attitude toward consumer, irrespective of market situation for a given product--does the company regard consumer loyalty important, or is it simply interested in quick profits?)

(b) Company's involvement with the community (1) Community welfare activities

(2) Educational institutions

(c) Company's relationship with local, state and federal governments

(d) Company's attitude and relationship with unions and union leaders

(e) Company's relationship with employees

(f) Company's relationship with suppliers and distributors 
Management Practice

While there is hardly any definitional

agreement as to the nature of management, the conceptual building blocks for such a definition as well as for comparison purposes are available. Management has been viewed as: (1) a particular group of men with distinctive qualities; (2) members of hierarchies invested with authority; and (3) a set of functions, in both senses of the term, that is, activities and contributions. 11

As used here, however, the term management practice pertains to the planning, organizing, directing, staffing, and controlling the operations of a business enterprise, or any unit part of such an enterprise, for the purpose of attaining the objective set for the business as a whole. 12

11J. Boddewyn, "Management: The Trees, The Forest and The Landscape," Management International Review, Nos. 2-3 (1967), pp. 131-136 ${ }^{12}$ william B. Cornel1, Business Organization (New York: Alexander Hami iton Institute, 1968), p. 241. 
The detailed description of the items is as follows: ${ }^{13}$

\begin{tabular}{ll}
\hline Managerial Function & $\begin{array}{l}\text { Description of Element } \\
\text { Which Should be Studied }\end{array}$ \\
\hline Planning & (a) Commitment period \\
& (b) Location of planning \\
& (c) Methodologies, techniques \\
& and tools used in plan- \\
ning
\end{tabular}

Organizing

(a) Authority-responsibility relationships

(b) Organization charts

(c) Degree of centralization and decentralization

(d) Span of control

(e) Degree of specialization

(f) The uses of informal organizations and management attitudes toward such group

(g) Grouping of activities and departmentation

(h) Uses of specialist staff and its relationship with line executives

Staffing

(a) Methods used in appraising, selecting and training personnel

(b) Promotion criteria used

(c) Management development practices used

\section{${ }^{13} \mathrm{~J}$. Boddewyn, Comparative Management and} Marketing (Glenview, ITlinois: Scott, Foresman and Company, 1969), p. 90. 
Directing

Controlling (a) The techniques used for motivating high level manpower to cooperate in achieving organizational objectives and goals

(b) The methods and techniques used for motivating workers

(c) Communication techniques used

(d) Supervisory techniques used

(a) Control techniques used for different areas, i.e., finance, production, marketing, etc.

(b) Types of control standards

(c) Information feedback systems and procedures for corrective actions

Management Performance

Management performance reflects the achievement of the objectives of a company. Obviously a company has multiple objectives. It must earn a profit if it is to continue in existence: earnings are necessary to attract additional capital and to provide a cushion for meeting the risks inherent in business activity. But for survival it is also essential that a company provide goods or services 
customers want, that its conditions of employment continue to attract competent employees, that it be a desirable customer to the people who supply raw materials, and that it be an acceptable corporate citizen in the community in which it operates. 14

In discussing the evaluation of management performance, multiple criteria will be needed. Here are some criterial identified by the General Electric Company as the key result areas.

(1) Profitability - in both percent of sales and return on investment.

(2) Market position.

(3) Productivity - which means improving costs as well as sales.

(4) Leadership in technological research.

(5) Development of future people, both technical or functional and managerial.

(6) Employee attitudes and relations.

(7) Public attitudes.

(8) Balance of long-range and short-range objjectives. 15

${ }^{14}$ William H. Newman, Charles E. Sumer, and E. Kirby Warren, The Process of Management (Englewood Cliffs, New Jersey: Prentice-Hal1, Inc. 1972), p. 412 .

${ }^{15}$ Ibid., p. 413. 
The following elements or factors are suggested by another source for ascertaining the degree of management performance. It is admitted that this list of factors is not exhaustive; however, all the factors combined will give an over-all idea of the effectiveness of the manager. These factors are:

(a) Net and gross profits in the last five years

(b) The percentage increase in profits in the last five years (year by year)

(c) Market share of the company in main product line and percent increase or decrease in market share in the last five years

(d) The market price of a company's stock and percent increase or decrease in prices in the last five years

(e) The percentage increase in sales during the last five years

(f) Employee morale and turnover

(g) Employees' evaluation of the company and ranking of the companies under study by the employees of each firm 

(h) Over-all evaluation of the company and ranking by the general public
(i) Evaluation of the company and ranking by the consumers 16

\section{Summary}

In sum, knowledge arises mostly out of comparison and the discovery of regularities. The greatest break-throughs in science have been made by those who saw comparability in phenomena previously thought to be unrelated. Indeed, according to Bronowsky, creativity in science occurs only when new comparabilities are seen. ${ }^{17}$ In contrast with the natural sciences, Weber argues, advances in the social sciences almost exclusively require the use of analogy, ${ }^{18}$ the type of comparative tool provides by classificatory schemes and checklists. Thus, the more sophisticated the mode of analysis used, the more comparability is being assumed.

\footnotetext{
16 J. Boddewyn, op. cit., pp. 90-91. $17 \mathrm{~J}$. Bronowsky, Science and Human Values (New York: Harper, Torchbook ed., 1959), pp. 23-32. ${ }^{18}$ Max Weber. The Methodology of the Social Science, trans. E. A. Shils and H. A. Finch
} 
In equilibrium analysis, for example, one can never know how appropriate a steady-state model is for a given phenomenon until some indices have been selected, quantified, and compared over time. 
CFAPTER III 


\section{DESIGN OF THE STUDY}

Conceptual Framework of the Study

The research proposes to identify and evaluate the existing management practices and management performance of Chinese specialty restaurants and American specialty restaurants.

The chi-square analysis, which is a method to test the significance of the difference between two statistics, ${ }^{1}$ is used to decide whether there is significant difference on practice and performance between the two caterories of restaurarts and whether the manacement practice has influence on the management performance. Figure 3-1 sketches the conceptual framework of the study. Further efforts are also made to identify the factors correlating to the profitability on investment as shown in Figure 3-2.

\footnotetext{
${ }^{1}$ Dick A. Leabo, Basic Statistics (Richard D. Irwin, Inc., 1968), p. 429.
} 
Figure 3-1

Conceptual Framework of the Study

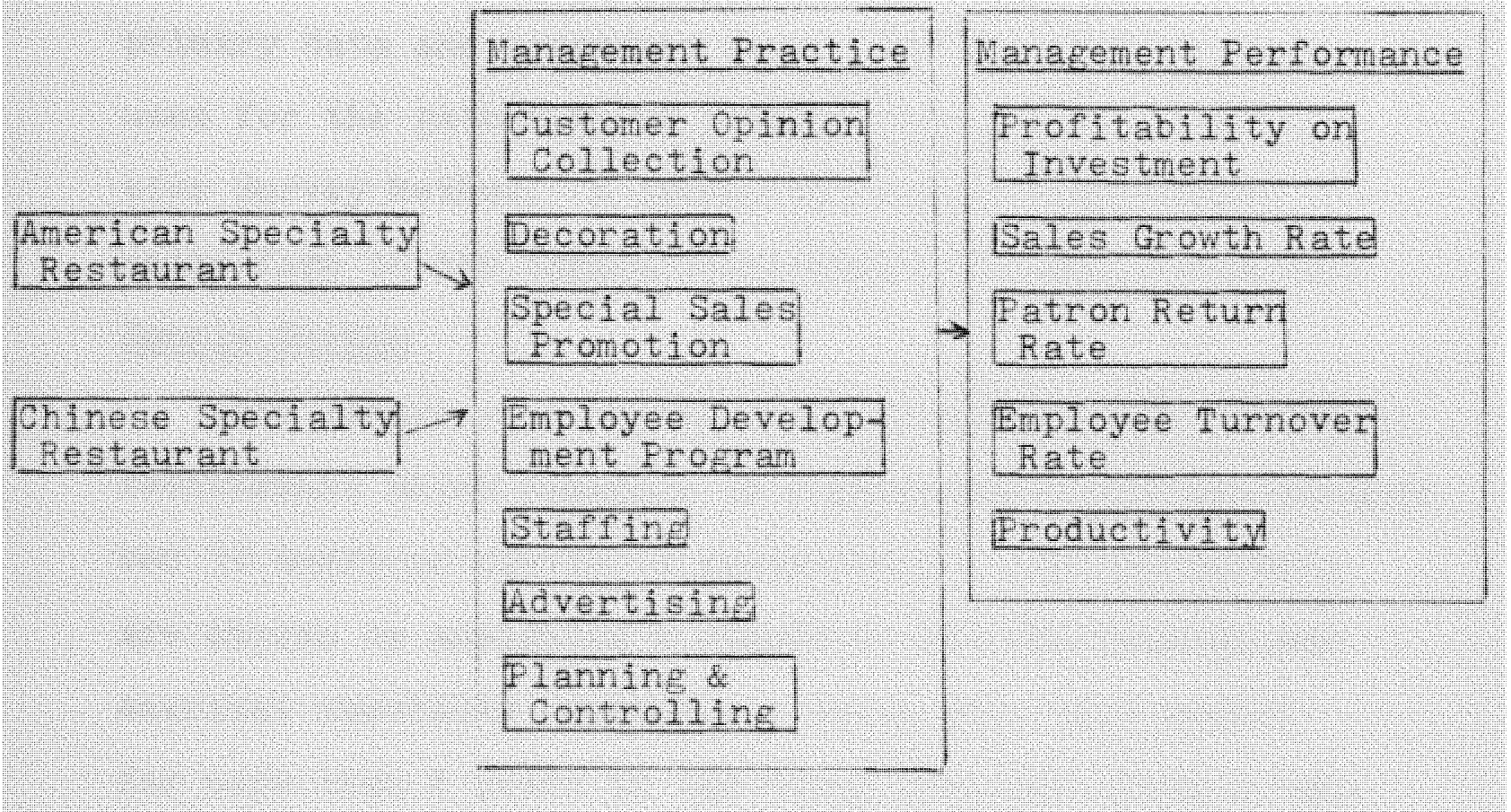

Figure 3-2

Correlation Factors of the Profitability

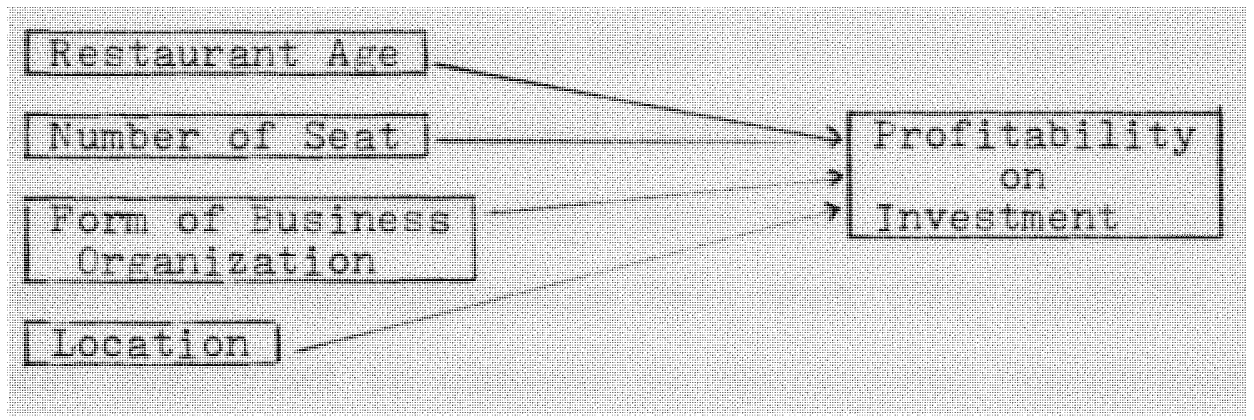


The Research riethodoloyy

The data of this research are of two kinds:

primary data and secondary data. The research method used for the gathering of primary data was the Descriptive Survey llethod. A survey presented in questionnaire form to the sample restaurants has been conducted. Sample Design

The sample size of the study encompassed 60 specialty restaurants which comprise 30 Chinese specialty restaurants and 30 American specialty restaurants. The restaurants are chosen by assignine a number to all the chinese and American specialty restaurants which have been opered for more than 2 years in the kiami area and using a random rumber takle.

In view of the fact that the nature of the information sought primarily deals with management performance as relating to management practices, management philosophies, the questionnaires were sent to the managers, or owners. It was generally felt that they would be the best qualified to comment on operational management philosophies, practices, and performance. 
The selection of this sample Eroup was made with the help of the following printed sources of Restaurant information:

(1) Greater Miami Yellow Fages "Restaurants"

(2) Miami liagazine "Restaurants"

(3) Guide to Restaurants of Greater Miami (1977) Questionnaire Desien

Questionnaire is designed to collect the information in 3 fields: the basic data of the restaurant, the management practice information, and the data for performance rating.

The questionnaires sent to the top executives (managers, or owners) of the sample restaurant companies, consisted of 21 questions covering 3 paces.

Page 1 of the questionnaire is desinned for the basic data of the restaurant. Question 1 through 10 primarily relate to management practice. Question 11 through 21 generally relate to management performance. Along with the questionnaire, a cover letter, a postage free return envelope, and a separate page clarifying urfamiliar terms were included in the survey 
packace mailed to the respective respordents. The survey envelopes were mailed through the use of first clase postage to insure the safety of undamaged delivery, along with the possi le enhancemert of quick responses. 
CHAPTER IV 
Management Fractice and

Management Ferformance Analysis

\section{Response Data}

The sources of data for this study are from either the owners, or the managers of the sample restaurants. They have important responsibilities, limit time schedules and commitments which keep them very busy. Some of them may not have been able to answer the questionnaires due to time constraints or the nature of the information sought may have elicited negative reactions. The recovery rate of the questionnaires is shown in Table 4-1.

$$
\text { Table 4-1 }
$$

Recovery Rate of the Questionnaires

\begin{tabular}{lccc}
\hline Sample Restaurant & Issuance & Response & Recovery Rate \\
\hline $\begin{array}{c}\text { Chinese Specialty } \\
\text { Restaurant }\end{array}$ & 30 & 24 & $80 \%$ \\
$\begin{array}{l}\text { American Specialty } \\
\text { Restaurant }\end{array}$ & 30 & 10 & $33.3 \%$ \\
$\quad$ Total & 60 & 34 & $56.7 \%$ \\
\hline
\end{tabular}

Management Practice Rating

The management practice rating system is to reflect the level of the management and marketing skills applied by the restaurant industry. 
The following items are major indicators selected to evaluate the management practice.

1. Customer opinion collection. The importance of the customer opinion collection can not be overlooked in light of the contribution of the feedback in the management cycle of planning, execution, and control.

Business can get customer opinion through ways like face to face, business reply card and other more. To evaluate this practice executed by the restaurant, one point is assigned to each communication way used to get customer opinion. Practice rating for the two categories is tabulated in Table 4-2.

$$
\text { Table } 4-2
$$

Management Practice - Customer Opinion Collection

\begin{tabular}{lcc} 
& Chinese & American \\
& Restaurant & Restaurant \\
\hline Face to Face & 22 & 10 \\
Business Reply Card & 3 & 10 \\
Other & 3 & 12 \\
\hline Average Rating & 1.17 & 3.2 \\
\hline
\end{tabular}

2. Decoration. Decoration is part of the product and service provided by the restaurant. Quality of decoration is really quality of product itself. For rating this item, 
no credit is given for those restaurants without redecoration in last 2 years. In less than 2 years, redecoration furnished by a professional designer is rated as 2 points, 1 point for redecoration done by an amateur designer. Table 4-3 lists the result of the rating. Table $4-3$

Management Practice - Decoration

\begin{tabular}{lcc}
\hline & $\begin{array}{c}\text { Chinese } \\
\text { Restaurant }\end{array}$ & $\begin{array}{c}\text { American } \\
\text { Restaurant }\end{array}$ \\
\hline Professional Designer & 10 & 5 \\
Amateur Designer & 3 & 4 \\
\hline Average Rating & 0.54 & 0.9 \\
\hline
\end{tabular}

3. Special Promotion. To bring in the maximum number of guests or patrons and to create special patronage, it is necessary that special promotion be utilized.

The evaluation of the practice is to assign 3 points to frequent special promotion, 2 points to occasional special promotion and 1 point to rare special promotion. Table $4-4$ tabulates the outcome. 


$$
\text { Table } 4-4
$$

lianazement Practice - Special Promotion

\begin{tabular}{lcc}
\hline & $\begin{array}{c}\text { Chinese } \\
\text { Restaurant }\end{array}$ & $\begin{array}{l}\text { American } \\
\text { Restaurant }\end{array}$ \\
\hline Frequently & 9 & 15 \\
Occasionally & 26 & 10 \\
Rarely & 8 & 0 \\
\hline Average Rating & 1.83 & 2.5 \\
\hline
\end{tabular}

4. Employee Development Program. Employee Development program is aimed at developing future people, both technical or functional and managerial to meet conpany's manpower in one end and is intended to satisfy the employee's desire for developing in the other end. The indicator used to evaluate the practice in this field is the frequency of employee development program. Restaurant has this kind of program annually is rated as 1 point. Those have the program semi-annually are rated 2 points. 3 points rating is credited to those have the program quarterly. The average rating is show in Table 4-5. 
Taise $4-5$

Hanagement Practice - Employee Development Frogram

\begin{tabular}{lcc}
\hline & $\begin{array}{c}\text { Chinese } \\
\text { Restaurant }\end{array}$ & $\begin{array}{c}\text { American } \\
\text { Restaurant }\end{array}$ \\
\hline Annually & 0 & 8 \\
Semi-Annually & 0 & 0 \\
Quarterly & 0 & 0 \\
\hline Average Rating & 0 & 0.8 \\
\hline
\end{tabular}

5. Staffing. The indicator for a company's staffing practice is what kind and how many professional staffs they have. To evaluate this, those restaurants have management school graduate staff is credited 2 points. Credit for employing non-management collere graduate is one point. The ratine is show in Tajle 4-6.

$$
\text { Table } 4-6
$$

Management Practice - Staffing

\begin{tabular}{lcc}
\hline & Chinese & American \\
& Restaurant & Restaurant \\
\hline Hianagement degree & 2 & 8 \\
Non-management degree & 11 & 6 \\
\hline Average rating & 0.54 & 1.4 \\
\hline
\end{tabular}

6. Advertising. Advertising is the purchased use of space or time for the purpose of selling or promoting a product or service to the public or a specific market. 
The advertising media include publications, radio, and tevevision and a variety of printed materials, including direct mail. Generally, advertising is broad-stroke selling that reaches wide areas of people.

To evaluate this practice, one point is assigned to each of the above-mentioned media used by the restaurant. The result is tabulated in Table 4-?.

$$
\text { Table 4-7 }
$$

Management Practice - Advertising

\begin{tabular}{lcc}
\hline & $\begin{array}{c}\text { Chinese } \\
\text { Restaurant }\end{array}$ & $\begin{array}{c}\text { American } \\
\text { Pestaurant }\end{array}$ \\
\hline Telephone book listing & 22 & 10 \\
Shopping center guides & 1 & 1 \\
Radio & 1 & 2 \\
Magazines & 0 & 2 \\
lewspaper & 4 & 4 \\
Tourist guide books & 4 & 4 \\
Television & 0 & 1 \\
Direct liail & 0 & 4 \\
\hline Average rating & 1.33 & 2.8 \\
\hline
\end{tabular}

7. Marketing management. Marketing management is a managerial activity which aims at understanding the potential markets which can be served and the environment within which a property must operate as it attempts to capture its share of those markets. Any restaurant operation can be improved through marketing. 
To evaluate the practice, 2-point is assigned to the restaurant that has marketing department or people in charge of marketing activities. Table $4-8$ tabulates the rating of this item.

$$
\text { Table } 4-8
$$

Management Practice - Dept. or People in charge of Marketing

\begin{tabular}{lcc}
\hline & Chinese & American \\
\hline Restaurant & 4 & 14 \\
No & 0 & 0 \\
\hline Average rating & 0.15 & 1.4 \\
\hline
\end{tabular}

8. Plannins and control technique. Planning is a basic manasement function. Without it, an enterprise would soon disintegrate; the pattern of its actions would de random. Control is the function to assure that the results of operations conform as closely as possible to establish goals and to provide timely information that may prompt revision of the goals. The major planning and control techniques listed below are used to rate the practice executed:

- Budgeting

- llanagement by objective

- Nianagerial Accounting

- Narketing Planning

- Service or Product Analysis 
Iach of the techniques used by the restaurant will be given 2 points. The rating is tasulated in Table 4-9.

$$
\text { Table } 4-9
$$

Management Practice - Planning \& Control Techniques

\begin{tabular}{lcc}
\hline & $\begin{array}{c}\text { Chinese } \\
\text { Restaurant }\end{array}$ & $\begin{array}{c}\text { American } \\
\text { Restaurant }\end{array}$ \\
\hline Budgeting & 10 & 18 \\
Management by Objective & 0 & 2 \\
Service or Product Analysis & 8 & 18 \\
Managerial Accounting Skill & 0 & 2 \\
Marketing Planning & 0 & 10 \\
\hline Average rating & 0.75 & 5 \\
\hline
\end{tabular}

Distribution of llanagement Practice Rating

The add-up of the above items comes out the total rating of management practice. Total point of 13 \& over is rated as excellent management practice. There are 12 restaurants; that is, 2 Chinese specialty restaurants, and 10 American specialty restaurants. Total point of $8-12$ is rated as good management practice. 7 restaurants, all are Chinese specialty restaurants, are rated as good. Total point of $6-7$ is rated as fair management practice. There are 5 Chinese specialty restaurants in this group. Total point of $5 \&$ under is rated as poor management practice. There are 10 Chinese restaurants. Table 4-10 summaries the result. 
Takle $4-10$

Distribution of lianasement Practice latine

\begin{tabular}{lccc}
\hline Practice rating & Chinese & American & Total \\
\hline Excellent & 2 & 10 & 12 \\
Good & 7 & 0 & 7 \\
Fair & 5 & 0 & 5 \\
Poor & 10 & 0 & 10 \\
\hline Total & 24 & 10 & 34 \\
\hline
\end{tabular}

Average management practice rating of Chinese special restaurant is 6.31. Average management practice rating of American specialty restaurant is 18 .

To test whether there is a significant difference of management practice between the two catecories, the expected frequencies are computed and shown in Table 4-11.

$$
\text { Table 4-11 }
$$

The Distribution of Expected Frequencies of lianagement Practice

\begin{tabular}{llcc}
\hline Practice Rating & $\begin{array}{l}\text { Chinese } \\
\text { Restaurant }\end{array}$ & $\begin{array}{l}\text { American } \\
\text { Restaurant }\end{array}$ & Total \\
\hline Excelient & $24 \times \frac{12}{34}=8.47$ & $10 \times \frac{12}{34}=3.53$ & 12 \\
Good & $24 \times \frac{7}{34}=4.94$ & $10 \times \frac{7}{34}=2.06$ & 7 \\
Fair & $24 \times \frac{5}{34}=3.53$ & $10 \times \frac{5}{34}=1.47$ & 5 \\
Poor & $24 \times \frac{10}{34}=7.06$ & $10 \times \frac{10}{34}=2.94$ & 10 \\
\hline Total & 24 & 10 & 34 \\
\hline
\end{tabular}


Here, the null hypothesis $H_{0}$ is that the Chinese specialty restaurant and American specialty restaurant have no significant difference on management practice. Using the .001 level of significance for $d f=(4-1)(2-1)=3$, the criteria for reaching a decision are:

$$
\begin{gathered}
\text { Accept } H_{0} \text { if } x_{c}^{2} \cong 16.268 \\
\text { Reject } H_{0} \text { if } x_{c}^{2}>16.268 \\
\text { Table } 4-12
\end{gathered}
$$

Computation of $\mathrm{x}_{\mathrm{c}}{ }^{2}$ of Management Practice

\begin{tabular}{cccccc}
\hline $\begin{array}{c}\text { Cell } \\
\text { Row-Column) }\end{array}$ & $\begin{array}{c}\text { Observed } \\
\text { Frequency } \\
f_{c}\end{array}$ & $\begin{array}{c}\text { Expected } \\
\text { Frequency } \\
f_{e}\end{array}$ & $f_{0}-f_{e}$ & $\left(f_{0}-f_{e}\right)^{2}$ & $\frac{\left(f_{c}-f_{e}\right)^{2}}{f_{e}}$ \\
\hline $1-1$ & 2 & 8.47 & 6.47 & 41.86 & 4.94 \\
$1-2$ & 10 & 3.53 & 6.47 & 41.86 & 11.86 \\
$2-1$ & 7 & 4.94 & 2.06 & 4.24 & 0.86 \\
$2-2$ & 0 & 2.06 & 2.06 & 4.24 & 2.06 \\
$3-1$ & 5 & 3.53 & 1.47 & 2.16 & 0.61 \\
$3-2$ & 0 & 1.47 & 1.47 & 2.16 & 1.47 \\
$4-1$ & 10 & 7.06 & 2.94 & 8.64 & 1.224 \\
$4-2$ & 0 & 2.94 & 2.94 & 8.64 & 2.94 \\
\hline & 34 & 34 & & $x_{c}{ }^{2}$ & 25.96
\end{tabular}

From Table 4-12, the computed value of $x_{c}{ }^{2}=25.96>16.268$, therefore the null hypothesis is rejected. The conclusion can be drawn that Chinese specialty restaurant and American specialty restaurant have significant difference on management practice. Comparine the average rating, American restaurant is apparently superior to chinese restaurant, as far as the management practice is concerned. 
Nanagement Ferformance Ratins

The management performance is also composed of the rating for the performance of several dimensions. The rating system is shown below item by item.

1. Profitability on investment. To differentiate the performance regarding the profitability on investment, the restaurant with a profitaility of $1^{\circ}$ \& over is rated 4 points. For the profitability of $9-14 \therefore, 3-8$, and under $3 \%$, the ratings are 3,2 , and 1 respectively. The distribution is tabulated in Table 5-1 and is analyzed in further in Chapter 5.

2. Sales Growth Rate. The rating system for sales growth rate: 4 points for growth rate of 15 \& over, 3 points for $10-14 \%$, 2 point for 5-9, and 1 point for rowth rate of under 5\%. The distriution and averare ratire are tabulated in Table 4-13.

Table $4-13$

The Distribution and Average Rating of Growth Rate

\begin{tabular}{ccc}
\hline Sales Growth Rate & $\begin{array}{c}\text { Chinese } \\
\text { Restaurant }\end{array}$ & $\begin{array}{c}\text { American } \\
\text { Restaurant }\end{array}$ \\
\hline $15 \%$ \& Over & 3 & 3 \\
$10 \%-14 \%$ & 8 & 5 \\
$5 \%-9 \%$ & 8 & 2 \\
Under $5 \%$ & 5 & 0 \\
Total & 24 & 10 \\
Average rating & 2.4 & 3.1 \\
\hline
\end{tabular}


3. Patron return rate. Following criteria are the rating for return patron.

4 points for patron return rate of $80 \%$ \& over.

3 points for patron return rate of $50,-79 \%$.

2 points for patron return rate of $25 \%-49 \%$.

1 point for patron return rate of Under 25:.

Table 4-14 presents the outcome.

$$
\text { Table } 4-14
$$

The Distribution and average rating of Patron Return Rate

\begin{tabular}{lcc}
\hline Patron Return Rate & Chinese & American \\
\hline 80 Restaurant & Restaurant \\
$50-79 \%$ & 5 & 2 \\
25 - 49 & 8 & 5 \\
Under 25i & 7 & 3 \\
Total & 24 & 0 \\
Average rating & 2.3 & 10 \\
\hline
\end{tabular}

4. Employee turnover rate. Rating system for employee turnover rate is as follows:

1 point for turnover rate of 100 \& Over.

2 points for turnover rate of $60 \%$ - $99 \%$.

3 points for turnover rate of $30 \%$ - $59 \%$.

4 points for turnover rate of Under $30 \%$

The distribution is shown in Table 4-15. 


$$
\text { Table } 4-15
$$

The Distribution and Average Rating of Employee Turnover Rate

\begin{tabular}{ccc}
\hline Employee Turnover Rate & Chinese & American \\
\hline 100, Restaurant & 3 & Restaurant \\
$60 \%-99$ & 6 & 3 \\
$30 \%-59$ & 8 & 3 \\
Under $30 \%$ & 24 & 0 \\
Total & 2.8 & 10 \\
Average Rating & 2.0 \\
\hline
\end{tabular}

5. Productivity. Productivity of $\$ 25$ \& over per man hour is rated as 4 points. \$20 - \$24/man hour is rated as 3. 315 $\$ 19 / \mathrm{man}$ hour is rated as 2 . Productivity under $\$ 15$ per man hour is rated as 1. The distribution is tabulated in Table 4-16.

$$
\text { Table } 4-16
$$

\begin{tabular}{|c|c|c|}
\hline Productivity ( $\$ /$ mar hour) & $\begin{array}{l}\text { Chinese } \\
\text { Restaurant }\end{array}$ & $\begin{array}{l}\text { American } \\
\text { Restaurant }\end{array}$ \\
\hline $\begin{array}{l}\$ 25 \& \text { Over } \\
320-\$ 24 \\
15-\$ 19 \\
\text { Under } \$ 15\end{array}$ & $\begin{array}{r}9 \\
10 \\
4 \\
1\end{array}$ & $\begin{array}{l}3 \\
4 \\
3 \\
0\end{array}$ \\
\hline Total & 24 & 10 \\
\hline Average nating & 3.13 & 3 \\
\hline
\end{tabular}

The Distrioution and Average Rating of Productivity

Distribution of Management Performance Rating

The total performance rating is obtained by adding the rating of each of the above items. To differentiate the management performance of the sample restaurant, criteria are established as beZllow: 
Restaurants with total points of 16 \& over are rated as excellent management performance. Among them 5 are chinese restaurants and 2 are American restaurants. Restaurants of 14 or 15 points are rated as good performance. 6 chinese restaurants and 5 American restaurants are so rated. Festaurants of 12 or 13 points are rated as fair performance. 9 chinese restaurants and 2 American restaurants are included in this group. Total points under 12 points are rated as poor performance. 4 Chinese restaurants and one American restaurant are on the list. The distribution is tabulated in Taule $4-17$.

$$
\text { Table 4-17 }
$$

The Distribution of Nanagement Performance Ratine

\begin{tabular}{lccc}
\hline $\begin{array}{c}\text { Performance } \\
\text { Rating }\end{array}$ & $\begin{array}{c}\text { Chinecc } \\
\text { Restaurante }\end{array}$ & $\begin{array}{c}\text { American } \\
\text { Restaurants }\end{array}$ & Total \\
\hline Excelient & 5 & 2 & 7 \\
Good & 6 & 5 & 11 \\
Fair & 9 & 2 & 11 \\
Poor & 4 & 1 & 5 \\
Total & 24 & 10 & 34 \\
\hline
\end{tabular}

Average management performance rating of Chinese Specialty restaurants is 13.96. Management performance rating of American Specialty resrtaurants is averaged at 14.5. The computation of expected frequencies is shown in Table 4-18. 


$$
\text { Tasle } 4-18
$$

Computation of Expecteo "requencies -

lianafement Ferformance Ratires

\begin{tabular}{lccc}
\hline Performance Rating & $\begin{array}{c}\text { Chinese } \\
\text { Restaurant }\end{array}$ & $\begin{array}{c}\text { American } \\
\text { Restaurant }\end{array}$ & Total \\
\hline Excellent & 4.94 & 2.06 & 7 \\
Good & 7.76 & 3.24 & 11 \\
Fair & 7.76 & 3.24 & 11 \\
Foor & 3.53 & 1.47 & 5 \\
$\quad$ Total & 24 & 10 & 34 \\
\hline
\end{tabular}

Here, the null hypothesis $H_{0}$ is that the chinese restaurant and the American restaurant have no significant difference on mana gement performance. Using the .1 level of sienificance, for $d f=(4-1)(2-1)=3$, the criteria for reachine a decision are:

$$
\begin{aligned}
& \text { Accept } H_{0} \text { if } x_{c}^{2} \leqq 6.2 .1 \\
& \text { Reject } H_{0} \text { if } x_{c}^{2}>6.251
\end{aligned}
$$

The computed value of $x_{c}^{2}$ is 2.248 which is less than 6.251 . Therefore the null hypothesis is accepted. The conclusion can be drawn that management performance of Chinese restaurant and that of American restaurant have no significant difference. I anagement Practice and lianagement Performance Correlation Test

Vill good management practice lead to good management performance? These two variables must be tested based on the same procedure in the last section to see if there is any correlation between them. 


$$
\text { Table 4-19 }
$$

The Distribution of ranarement Ferformance against lianacement Fractice

\begin{tabular}{lccccc}
\hline Practice & Excelient & Good & Fair & Poor & Total \\
Performance & 4 & 1 & 1 & 1 & 7 \\
\hline Excelient & 5 & 2 & 1 & 3 & 11 \\
Good & 2 & 4 & 3 & 2 & 11 \\
Fair & 1 & 0 & 0 & 4 & 5 \\
Poor & 12 & 7 & 5 & 10 & 34 \\
Total & & & & & \\
\hline
\end{tabular}

To do so, the distribution of llanagement performance against management practice is prepared and shown in Table 4-19. The computed expected frequencies are tabulated in Table 4-20.

$$
\text { Table 4-20 }
$$

Expected Frequency of lianarement Performance arainct lianagement Fractice

\begin{tabular}{llllll}
\hline Practice & Excelient & jood & Pair & Poor & Total \\
Performance & & & & & \\
\hline Excellent & 2.47 & 1.44 & 1.03 & 2.06 & 7 \\
Good & 3.88 & 2.26 & 1.62 & 3.24 & 11 \\
Fair & 3.88 & 2.26 & 1.62 & 3.24 & 11 \\
Foor & 1.76 & 1.03 & 0.73 & 1.47 & 5 \\
$\quad$ Total & 12 & 7 & 5 & 10 & 34 \\
\hline
\end{tabular}

The null hypothesis $\mathrm{H}_{0}$ here is that the management performance has no correlation with the manaement practice. Using the .01 level of significance, for $d f=(4-1)(4-1)=9$, the criteria for reaching a decision are: 


$$
\begin{aligned}
& \text { Accept } H_{0} \text { if } X_{c}^{2} \leqq 14.684 \\
& \text { Reject } H_{0} \text { if } X_{c}^{2}>14.684
\end{aligned}
$$

The computed value of $x_{c}^{2}$ is 12.57 which is less than 14.684. The conclusion can be drawn that restaurant management practice has no significant effect on management performance. It is also clearly understood from the fact that American restaurant has absolutely superior management practice to that of Chinese restaurant, but end up with similar management performance to that of chinese restaurant. 
CHAPRER V 
Profitability Analysis

A company must earn a profit if it is to continue in existence: earnings are necessary to attract additional capital and to provide a cushion for meeting the risks inherent in business activity. In this chapter, efforts will be made to identify the factors correlating to the profitability of the restaurant business.

Profitability Comparison between Chinese and American Restaurant

$$
\text { Table 5-1 }
$$

The Occurrence of Profitability of Chinese and American Restaurant

\begin{tabular}{|c|c|c|c|}
\hline Profitability & $\begin{array}{l}\text { Chinese } \\
\text { Restaurant }\end{array}$ & $\begin{array}{l}\text { American } \\
\text { Restaurant }\end{array}$ & Total \\
\hline $15 \%$ \& over & 14 & 5 & 19 \\
$9 \%-14 \%$ & 6 & 5 & 11 \\
$3 \%-8 \%$ & 2 & 0 & 2 \\
Under 3\% & 2 & 0 & 2 \\
Total & 24 & 10 & 34 \\
\hline
\end{tabular}

Table 5-1 is the occurrence of profitability of Chinese and American restaurant. 
The computed expected frequencies are tasulated in Table $5-2$.

Table $5-2$

Computation of Expected Frequencies Frofitability of Chinese and American Restaurant

\begin{tabular}{|c|c|c|c|}
\hline Profitability & $\begin{array}{l}\text { Chinese } \\
\text { Restaurant }\end{array}$ & $\begin{array}{l}\text { American } \\
\text { Restaurant }\end{array}$ & Total \\
\hline $15 \%$ over & $24 \times \frac{19}{34}=13.41$ & $10 \times \frac{19}{34}=5.59$ & 19 \\
$9 \%-14 \%$ & $24 \times \frac{11}{34}=7.76$ & $10 \times \frac{11}{34}=3.24$ & 11 \\
$3 \%-8 \%$ & $24 \times \frac{2}{34}=1.41$ & $10 \times \frac{2}{34}=0.59$ & 2 \\
Under 3\% & $24 \times \frac{2}{34}=1.41$ & $10 \times \frac{2}{34}=0.59$ & 2 \\
Total & 24 & 10 & 34 \\
\hline
\end{tabular}

The null hypothesis is that chinese restaurant and American restaurant have no significant difference on profitability. For 0.1 level of significance and $d f=(4-1)(2-1)=3$, the criteria for reaching a descision are:

$$
\begin{aligned}
& \text { Accept } H_{0} \text { if } x_{c}^{2} \leqq 6.251 \\
& \text { Reject } H_{0} \text { if } x_{c}^{2}>6.251
\end{aligned}
$$




$$
\text { Table 5-3 }
$$

Computation of $\mathrm{X}_{\mathrm{C}}^{2}$ -

PROFITAOIIITY OF CHINESE AND ANERICAN RESTAURANT

\begin{tabular}{cccccc}
\hline $\begin{array}{c}\text { Cell } \\
(\text { Row-Colum })\end{array}$ & $\begin{array}{c}\text { Observed } \\
\text { Frequency } \\
f_{0}\end{array}$ & $\begin{array}{c}\text { Expected } \\
\text { Frequency } \\
f_{e}\end{array}$ & $f_{c}-f_{e}$ & $\left(f_{0}-f_{e}\right)^{2}$ & $\frac{\left(f_{0}-f_{e}\right)^{2}}{f_{e}}$ \\
\hline $1-1$ & 14 & 13.41 & 0.59 & 0.348 & 0.026 \\
$1-2$ & 5 & 5.59 & -0.59 & 0.348 & 0.063 \\
$2-1$ & 6 & 7.76 & -1.76 & 3.098 & 0.4 \\
$2-2$ & 5 & 3.24 & 1.76 & 3.10 & 0.96 \\
$3-1$ & 2 & 1.41 & 0.59 & 0.348 & 0.25 \\
$3-2$ & 0 & 0.59 & -0.59 & 0.348 & 0.59 \\
$4-1$ & 2 & 1.41 & 0.59 & 0.348 & 0.25 \\
$4-2$ & 0 & 0.59 & -0.59 & 0.348 & 0.59 \\
\hline & 34 & 34 & & $x_{c}^{2}=3.129$
\end{tabular}

From Table 5-3, the computed value of $\mathrm{x}_{c}{ }^{2}=3.129<6.251$; therefore the null hypothesis is accepted. The conclusion can be drawn that profitability of American specialty restaurant and Chinese specialty restaurant have no significant difference. 


\section{Affecting Factors Identification}

1. Restaurant Age. Table 5-4 is the distribution of profitability against restaurant age.

$$
\text { Table } 5-4
$$

Distribution of Profitability against Restaurant Age

\begin{tabular}{|l|c|c|c|c|c|}
\hline Profitabbility & $15 \%$ \& over & $9 \%-14 \%$ & $3 i-8 \%$ & Under $3 ;$ & Total \\
\hline Age & 3 & 3 & 0 & 0 & 6 \\
6,7 & 8 & 2 & 0 & 0 & 10 \\
4,5 & 7 & 2 & 2 & 1 & 12 \\
2,3 & 1 & 4 & 0 & 1 & 6 \\
\hline Total & 19 & 11 & 2 & 2 & 34 \\
\hline
\end{tabular}

The expected frequencies are tabulated in Table 5-5.

$$
\text { Ta'se } 5-5
$$

Computation of Expected Frequencies -

\begin{tabular}{|c|c|c|c|c|c|}
\hline $\begin{array}{r}\text { Profita- } \\
\text { bility }\end{array}$ & $15 \%$ \& Over & $99-14$ & $3 \pi-8$ & Under 3: & Total \\
\hline $8,9, \&$ Over & $\frac{6}{34} \times 19=3.353$ & $\frac{6}{34} \times 11=1.941$ & $\frac{6}{34} \times 2=0.353$ & $\frac{6}{34} \times 2=0.353$ & 6 \\
\hline 6.7 & $\frac{10}{34} \times 19=5.588$ & $\frac{10}{34} \times 11=3.236^{*}$ & $\frac{10}{34} \times 2=0.588$ & $\frac{10}{34} \times 2=0.588$ & 10 \\
\hline 4,5 & $\frac{12}{34} \times 19=6.706$ & $\frac{12}{34} \times 11=3.882$ & $\frac{12}{34} \times 2=0.706$ & $\frac{12}{34} \times 2=0.706$ & 12 \\
\hline 2,3 & $\frac{6}{34} \times 19=3$ & $\frac{6}{34} \times 11=1$. & $\frac{6}{34} \times 2=0$ & $\frac{6}{34} \times 2=0.353$ & 6 \\
\hline Total & 19 & 11 & 2 & 2 & 34 \\
\hline
\end{tabular}

Frofitability against Restaurant Age

*Rounded to make totals agree. 
The null hypothesis is that there is no important effect between age of restaurant and profitability of restaurant. Using the. 1 level of significance and $d f=(4-1)(4-1)=9$, the criteria are:

$$
\begin{aligned}
& \text { Accept } \mathrm{H}_{0} \text { if } \mathrm{x}_{\mathrm{c}}^{2} \leqq 14.684 \\
& \text { Reject } \mathrm{H}_{0} \text { if } \mathrm{x}_{\mathrm{c}}^{2}>14.684 \\
& \text { Table } 5-6 \\
& \text { Computation of } \mathrm{x}_{\mathrm{c}}^{2}-
\end{aligned}
$$

Frofitability against Restaurant Age

\begin{tabular}{cccrcc}
\hline $\begin{array}{c}\text { Cell } \\
(\text { Row-Colum })\end{array}$ & $\begin{array}{c}\text { Observed } \\
\text { Frequency } \\
f_{c}\end{array}$ & $\begin{array}{c}\text { Expected } \\
\text { Frequency } \\
f_{e}\end{array}$ & $f_{c}-f_{e}$ & $\left(f_{c}-f_{e}\right)^{2}$ & $\frac{\left.f_{0}-f_{e}\right)^{2}}{f_{e}}$ \\
\hline $1-1$ & 3 & 3.353 & -0.353 & 0.125 & 0.037 \\
$1-2$ & 3 & 1.941 & 1.059 & 1.121 & 0.578 \\
$1-3$ & 0 & 0.353 & -0.353 & 0.125 & 0.354 \\
$1-4$ & 0 & 0.353 & -0.353 & 0.125 & 0.354 \\
$2-1$ & 8 & 5.588 & 2.412 & 5.818 & 1.041 \\
$2-2$ & 2 & 3.236 & -1.236 & 1.528 & 0.472 \\
$2-3$ & 0 & 0.588 & -0.588 & 0.346 & 0.588 \\
$2-4$ & 0 & 0.588 & -0.588 & 0.346 & 0.588 \\
$3-1$ & 7 & 6.706 & 0.294 & 0.086 & 0.013 \\
$3-2$ & 2 & 3.882 & -1.882 & 3.542 & 0.912 \\
$3-3$ & 2 & 0.706 & 1.294 & 1.674 & 0.371 \\
$3-4$ & 1 & 0.706 & 0.294 & 0.086 & 122 \\
$4-1$ & 1 & 3.353 & -2.353 & 5.537 & 1.651 \\
$4-2$ & 4 & 1.941 & 2.059 & 4.239 & 0.354 \\
$4-3$ & 0 & 0.353 & -0.353 & 0.125 & 1.187 \\
$4-4$ & 1 & 0.353 & 0.647 & 0.419 & $x_{c}^{2}=12.806$ \\
& 34 & 34 & & &
\end{tabular}


Because $x_{c}^{2}=12.806<14.684$, the null hypothesis is accepted; that is, the conclusion can be drawn that the age of restaurant is irrelevant to the profitability of the restaurant.

2. Number of seat. Table 5-7 is the distribution of profitability against restaurant size.

$$
\text { Table 5-7 }
$$

Distribution of Frofitability against Restaurant Size

\begin{tabular}{|c|c|c|c|c|c|c|c|c|c|}
\hline \multirow{2}{*}{$\begin{array}{r}\text { Profita } \\
\text { beat }\end{array}$} & \multicolumn{2}{|c|}{$15: \&$ Over } & \multicolumn{4}{|c|}{$9 m-14 \% 35-8$} & \multicolumn{2}{|c|}{ Under $3 \%$} & \multirow{2}{*}{ Total } \\
\hline & $f_{c}$ & $f_{e}$ & $f_{0}$ & fe & $f_{c}$ & $f_{e}$ & $f_{0}$ & $f_{e}$ & \\
\hline over 120 & 8 & 6.147 & 1 & 3.559 & 1 & 0.647 & 1 & 0.647 & 11 \\
\hline $101-120$ & 5 & 7.824 & 9 & 4.529 & 0 & 0.824 & 0 & 0.824 & 14 \\
\hline $80-100$ & 5 & 3.912 & 1 & 2.265 & 1 & 0.412 & 0 & 0.412 & 7 \\
\hline Unäer 80 & 1 & 1.118 & 0 & 0.647 & 0 & 0.118 & 1 & 0.118 & 2 \\
\hline Total & 19 & 19 & 111 & & 2 & 2 & 2 & 2 & 34 \\
\hline
\end{tabular}

The null hypothesis is that the size of restaurant is not correlated with the profitability of restaurant. Using the .05 level of significance and $d f=(4-1)(4-1)=9$, the criteria for reaching a decision are:

$$
\begin{aligned}
& \text { Accept } H_{0} \text { if } x_{c}^{2} \leqq 16.919 \\
& \text { Reject } H_{0} \text { if } x_{c}^{2}>16.919
\end{aligned}
$$


The computed value of $x_{c}^{2}=19.502>16.919$; therefore the null hypothesis is rejected. The conclusion can be drawn that the size of restaurant is correlated with the profitability of restaurant.

Profitability rating for the eleven restaurants which have seats over 120 is averaged at 3.455. Eight of them, representing $72.73 \%$, have $15:$ \& over profitability. For the fourteen restaurants with seats of 100-120, the averace rating is 3.357. Five of them, which account for $35.71 \%$, have profitability of $15 \% 8$ over. The average profitability rating for the seven restaurarts with seatr of $80-100$ is 3.57 . Five of them; i.e. $71.43^{\prime}$, have 15 \& over profitability. The two restaurants with seats of under 80 have average profitability rating of 2.5 .

Figure 5-1 is a plot of profitability rating against number of seats. The restaurants with seats of 80-100 have the best profitability rating.

Figure 5-1 Curve of Profitability Rating vs. No. of Seat

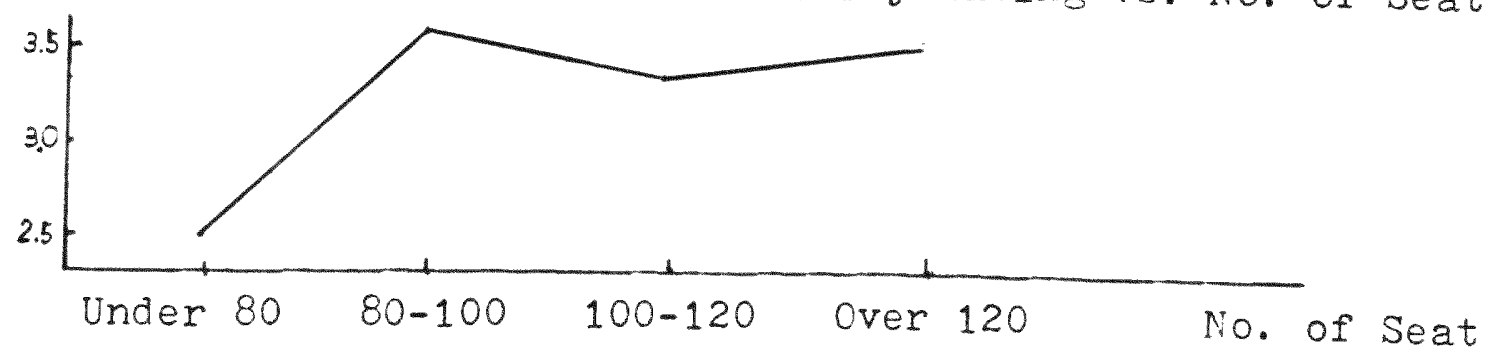


3. Form of usiness Organization. Table 5-8 is the distribution of profitability against business form.

$$
\text { Table 5-8 }
$$

Distribution of Profitability aeainst Business Form

\begin{tabular}{|c|c|c|c|c|c|c|c|c|c|}
\hline $\begin{array}{r}\text { Profita- } \\
\text { bility }\end{array}$ & $15 \%$ & \& Over & $9 i$ & $14 \%$ & & -8 & & $\operatorname{er} 3 \%$ & Total \\
\hline organization & $f_{e}$ & $f_{e}$ & $f_{0}$ & $f_{3}$ & $\overline{f_{c}}$ & $f_{e}$ & $f_{c}$ & $f_{e}$ & \\
\hline $\begin{array}{l}\text { Sole Pro- } \\
\text { prietorship }\end{array}$ & 10 & 7.265 & 3 & 4.206 & 0 & 0.765 & 0 & 0.765 & 13 \\
\hline Partnership & 8 & 7.265 & 2 & 4.206 & 2 & 0.765 & 1 & 0.765 & 13 \\
\hline Corporation & 1 & 4.471 & 6 & 2.588 & 0 & 0.471 & 1 & 0.471 & 8 \\
\hline Total & 19 & 19 & 11 & 11 & 2 & 2 & 2 & 2 & 34 \\
\hline
\end{tabular}

The null hypothesis is that the form of business organization is not relevant to the profitability of restaurant. Using the .05 level of significance and $d f=(4-1)(3-1)=6$, the criteria are:

$$
\begin{aligned}
& \text { Accept } H_{0} \text { if } x_{c}{ }^{2} \leqq 12.592 \\
& \text { Reject } H_{0} \text { if } x_{c}{ }^{2}>12.592
\end{aligned}
$$

Because $x_{c}^{2}=14.46>12.592$, the null hypothesis is rejected. The conclusion can be draw that the form of business organization is relevant to the profitability of the restaurant. 
Profitability rating for the thirteen restaurants which are sole proprietorship is averaged at 3.769. Ten of them, representing $76.9 \%$, have profitability of $15 \%$ \& over. The averace profitability rating for the thirteen restaurants which are in the form of partnership is 3.308. Eight of them, which account for $61.5 \%$, have profitability of $15 \%$ \& over. The eisht restaurants with the form of corporation have average profitability rating of 2.875. Only one of them has profitability of $15 \%$ \& over. Figure 5-2 is a plot of profitability rating against form of or canizatjon. It shows that the sole proprietorship has the best profitability.

Figure 5-2

Curve of profitability Rating vs. Form of Organization

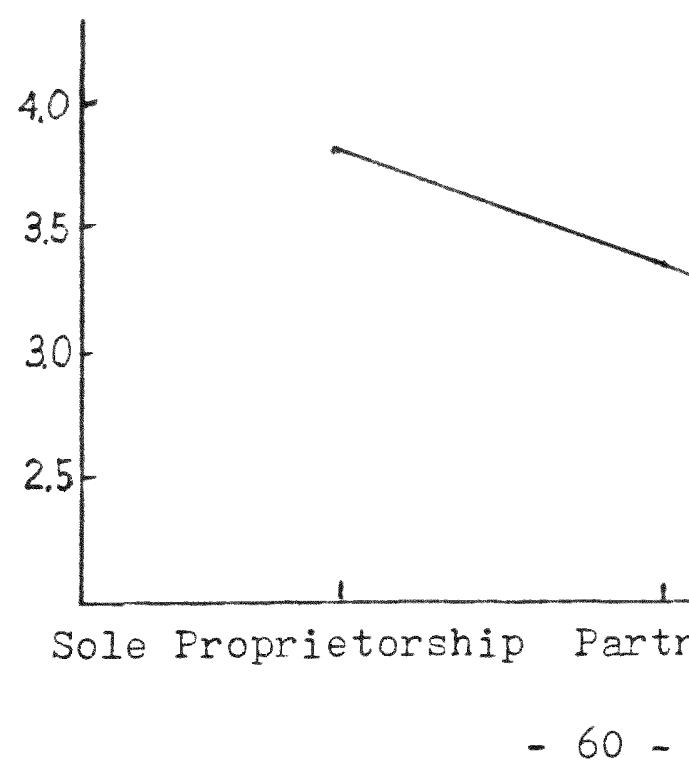


4. Location. Table 5-9 is the distribution of profitability against location.

Table 5-9

Distribution of Profitability against Location

\begin{tabular}{|c|c|c|c|c|c|c|c|c|}
\hline \multirow[b]{2}{*}{ Docation } & $15 \%$ \& Over & \multicolumn{2}{|c|}{$=9 \%-14 \%$} & \multicolumn{2}{|c|}{$3 \%-8 ; \%$} & \multicolumn{2}{|c|}{ Under 3} & \multirow{2}{*}{ Total } \\
\hline & $f_{0} f_{t}$ & $E_{c}$ & fe & $f_{c}$ & $f_{e}$ & $f_{0}$ & fe & \\
\hline Commercial & $14 \quad 11.73$ & 7 & 6.79 & 0 & 1.24 & 0 & 1.24 & 21 \\
\hline Residential & 7.26 & 4 & 4.21 & 2 & 0.76 & 2 & 0.76 & 13 \\
\hline Total & $19 \quad 19$ & 11 & 11 & 2 & 2 & 2 & 2 & 34 \\
\hline
\end{tabular}

The null hypothesis is that the location of the restaurant is not correlated with the profitability of the restaurant. Using the .1 level of significance and $d f=(4-1)(2-1)=3$, the criteria are:

$$
\begin{aligned}
& \text { Accept } H_{0} \text { if } x_{c}^{2} \leqq 6.251 \\
& \text { Reject } H_{0} \text { if } x_{c}^{2}>6.251
\end{aligned}
$$

The computed value of $x_{c}^{2}=7.68>6.251$, the null hypothesis is rejected; that is, the conclusion can be drawn that the location of the restaurant has an important effect on the profitability of the restaurant. 
Profitability rating for the 21 restaurants located in Commercial area is 3.67 . Fourteen of them, representing $66.67 \%$, have profitability of $15 \%$ \& over. The average profitability rating for the thirteen restaurants located in Residential area is 2.92. Five of them, which account for $38.46 \%$, have $15 \%$ \& over profitability. Evidently, commercial area is the proper location for the restaurant operation. 


\section{CHAPTER VI}




\section{CONCLUSIONS AND RECOMMENDATIONS}

The conclusions to be drawn from this study are as follows:

1. The management of Chinese specialty restaurants are exposed to the same environment of advanced marketing and management technology as the management of American specialty restaurants. Jut their low rating of management practice points out that they are not adopting and applying those techniques.

2. Chinese specialty rectaurants are especially rated poor on items of stafing professional people and holding employee development procram. They are reluctant to hire manarement school eraduates and are apending few money on employee development program. This might be one of the main factors lead to their low management practice rating.

3. The study shows no significant difference on management performance between the two categories of restaurants. The American specialty restaurants average better on sales growth rate and patron return rate. on the other hand, Chinese specialty restaurants have lower employee turnover rate. Both of them have similar profitability and productivity. The low employee turnover rate of Chinese specialty restaurants might be 
originated from the facts 1) that chinese people have higher loyalty to their employer and 2) that it is not easy for them to change their jobs in a foreinn environment.

4. The correlation test shows that management practices have no direct influence on management performance.

Recommendations

First of all, in respect of profitability, the study shows that number of seats, form of business organization, and location are influencing factors.

1. Number of seats. Seats of 80-100 is the most profitable restaurant size.

2. Form of business organization. Sole proprietorship is the most profitable form of restaurant organization.

3. Location of restaurant. Commercial area is the proper location for the restaurant operation.

Secondly, with respect to management practice, Chinese specialty restaurants have lower rating. It is recommended that Chinese specialty restaurants 1) hire more professional management chool graduates to operate more efficiently and profitably 2) put stress on application 
of principles of foodservice manarement, which are objective principle, market principle, ay,tem.; principle, planning principle, adaptation principle, limitedresource principle, and people principle.

Lastly, it is possible to sugrest that the success of foodservice managers lies in their appreciation and application of principles of foodservice management; that the prosperity of an operation is due to it: ability to adapt to changed or changing conditions. Remember! All the foodservice operators, especially Chinese restaurant operators! "To fail to change is to fail." 


\section{BIBLIOGR APHY}

\section{Books}

Boddewyn, J. Comparative Management and Marketing. Glenview, Illinois: Scott, Foresman and Company, 1969.

Bronowsky, J. Science and Human Values.

New York: Harper, Torchbook ed., 1959.

Clark, Donald T., and Gottfried, B. A. University Dictionary of Business and Finance. New York: Thomas Y. Crowell Co., 1957.

Coffman, C. Dewitt. Hospitality For Sale. East Lansing, Michigan: The Educational Institute of the American Hotel \& Motel Association, 1980.

Cornell, William B. Business Organization. New York: Alexander Hamilton Institute, 1968.

Harbison, Frederick, and Myers, Charles. Management in the Industrial World. New York: McGraw-Hill Book Company, 1959.

Leabo, Dick A. Basic Statistics. Homewood, Illinois: Richard D. Irwin. Inc., 1968.

Marsh, A. I., and Evans, E. O. The Dictionary of Industrial Relations. London: Hutchinson Educational Ltd. . 1973.

Moore, Norman D. Dictionary of Business Finance and Investment. Dayton, Ohio: Investor's Systems, Inc. , 1975.

Newman, William H., Summer, Charles E., and Warren, E. Kirby. The Process of Management. Englewood Cliffs, New Jersey: Prentice-Hall, Inc., 1972.

Roberts, Harold S. Roberts Dictionary of Industrial Relations. Washington, D.C.: The Bureau of National Affairs, Inc., 1971. 
Sakamoto, N. The People's Republic of China Cookbook. New York: Random House, Inc., 1977.

Shafritz, Jay M. Dictionary of Personnel Management and Labor Relations. Oak Park. Illinois: Moore Publishing Company, Inc., 1980.

Weber, Max. The Methodology of the Social Science, trans. E. A. Shils and H.A. Finch. Glencoe: Free Press, 1949.

\section{Periodicals}

Boddewyn, J. "The Comparative Approach to the Study of Business Administration." Academy of Management Journal, Vol. 8, No. 4 (December, 1965).

Boddewyn, J. "Management: The Trees, The Forest and The Landscape," Management International Review, Nos. 2-3 (1967).

Farmer, Richard and Richman, Barry. "A Model for Research in Comparative Management," California Management Review (Winter, 1964).

Gonzalez, Richard F, and McMillan, Claude Jr. "The University of American Management Philosophy," Journal of the Academy of Management, Vol. 4, No. 1 (April, 1961).

Haas, Michael. "Comparative Analysis," Western Political Quarterly, Vol. XV, No. 2 (June, 1962).

Merrill, Harwood E. "Listening Post," Management News, Vol. 36, No. 1 (January 1963).

Oberg, Winston. "Cross-Cultural Perspectives on Management Principles," Journal of the Academy of Management, Vol. 6, No. 2 (June 1963).

Schollhammer, Hans. "Strategies and Methodologies in International Business and Comparative Management Research," Management International Review, vol. 13. No. 6 (1973). 


\title{
AFFENDIX A
}

\section{Title of the Study}

CONPARATIJE IMANAGENENT FERFORIANCE

OF CHINESE SEECIAITY RESTAURANT

AND ARERICAN SEECIAITY PESTAURANT

IN MIANI AREA

\begin{abstract}
Sponsorine Arency or Inetitution
school of Hospitality llanacement

Iorica Ir.ternational Univerrity
\end{abstract}

Return the completed questionnaire to:

Shu-Nuan Tarya Chin

12564 S. 267 Terrace

Naranja, Fla. 33032 
Shu-Nuan Tanya Chin 12564 Sil 267 Terrace Naranja, Florida 33032

Dear Sir,

In conjunction with fulfilling the requirements for a Master's Degree in Hospitality llanagement Administration at Florida International University, I am conducting a survey on Management Practice and Management Performance of specialty restaurants. You are selected as one of the sample restaurants.

The following questionnaire is designed to collect the information concerning the management practices you are using and management performance you might accomplish. Hopefully we can find some correlation factors lead to the improvement of the performance so that the industry can benefit from this finding.

Your answer to the questions will be most helpful and highly appreciated.

$$
\text { very truly yours, }
$$


AFFENDIX C

Clarification of Terms

Management by objective - is a process specifying that superiors and those who report to them will jointly establish objectives over a specified time frame, meeting periodically to evaluate their progress in meetings these goals.

Managerial Accounting - is a resource of management that supplies financial information at all levels to be used in the planning and administering of the business. Various techniques include: standard costing and budgetary control.

Management Development Program - is a leadership training for middle- or top- level personnel to upgrade their skills.

Absenteeism Rate - is a measure of the amount of absenteeism in an industrial estajishment, usually ortained by dividing the total numer of employee days or hours lost by assence by the total number of employee days or hours assigned for work during the period.

Employee Turnover Rate - Movement of individuals into, through, and out of an organization. Turnover can be statistically defined as the total number (or percentage) of separations that occurs over a given time period. The turnover rate is an important indicator of the morale and health of an organization. Turnover rate = number of employee separations/total number of employee. 
Appendix D

\section{QUESTIONNAIRE}

Restaurant Name

Address

Business history

years.

Business hour days a week.

No. of seats in the dining room

Bar Yes

No

Take-out service

Yes No

Car parking facilities

Do you serve Beverage (wine)?

Yes No

Do you present live entertainment? Yes No

Where is your establishment located?

Commercial District

Residential District other, please describe.

What is your operation type? Freestanding Hotel restaurant

Franchised other, please describe.

What is the form of your business organization?

Sole proprietorship

Partnership

Corporation

other, please describe. 
1. How do you get opinions from your customers? Face to face

Business reply card None for the last year other, please describe

2. How long has it been since you've completely redecorated? By Professional Designer Amateur Designer

3. How often do you arrange Special Sales Promotion?

Frequently Rarely occasionally Never

4. How often do you have Iranagement (Employee) Development Program? Annually Quarterly Semi-annually Never

5. What type of Training Program do you have?

6. How well do you know your customer patronage? Very weII No idea Fair

7. What kind of advertising do you ever run for the past 6 months? Telephone book listings

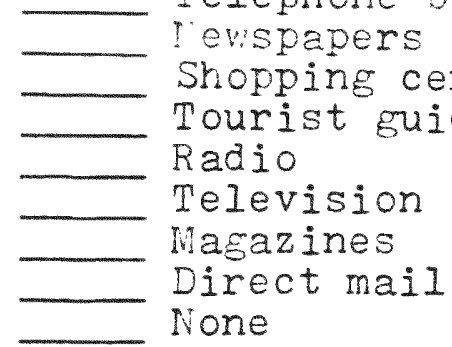

8. Do you have any departments or people in charge of sales (or marketing) promotion or advertising affairs? Yes No

9. Do you have any of the following management techniques in the past year? Budgeting Managerial Accounting Skill lianagement by objective Marketing Planning Service or Product Analysis

10. Employee's salary is reviewed once a year. reviewed once per 6 months. not reviewed in the past year. 
11. How many workers? Full time - Part time day.

12. For the full-time worker -

How many manazement school graduate?

How many non-management college/university graduate?

13. How many dollars does 1 hour of labor bring in?

14. What is your Profitability as percent of sales?

$$
\begin{aligned}
& 15 \% \text { \& Over } \\
& \text { 3. - } 8 \\
& 9=14 \\
& \text { Under } 3 \text {; }
\end{aligned}
$$

15. What is your Frofitability on Investment?

$$
\begin{aligned}
15 \% \text { over } & -8 \\
- & -14 \\
&
\end{aligned}
$$

16. S-les volume for the past three year (If you don't have the exact figures, please give your estimation). $1981+1980$ - 1979

17. Percentage of return patrons

$$
\begin{aligned}
& 80: \text { \& Cver } \\
& 25^{\circ}-49 \%
\end{aligned}
$$$$
500^{\circ}-79
$$$$
\text { Under } 25
$$

18. What's the employee turnover rate based on one year?

(number of employee separations/total number of employee)

$100 \%$ Cver $-60^{\circ}-99^{\circ}$
$-30^{\circ}-59^{\circ}=$ Under $30^{\circ}$

19. What's your food cost percentage?

20. What's your labor cost percentage?

21. What's your absenteeism rate?

I wish to express my extreme thanks to you and your organization for the time and cooperation you have given me in the fulfillment of this project.

Sincerely yours,

Shu-luan Tanya Chin 